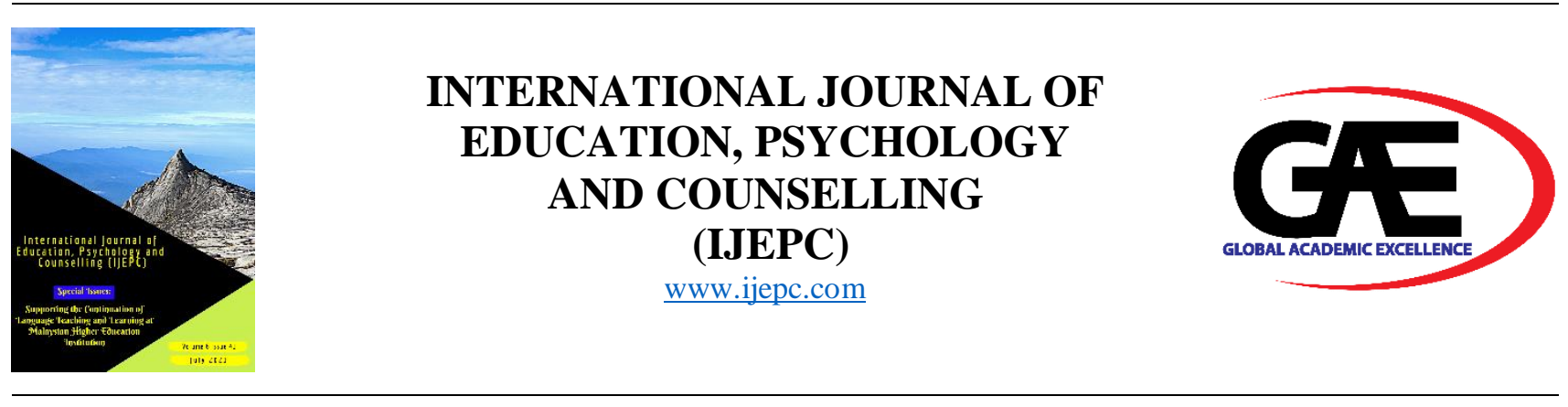

\title{
A CASE STUDY ON STUDENTS' REASONS FOR NOT SWITCHING ON THEIR CAMERAS DURING ONLINE CLASS SESSIONS
}

\author{
Bernadette Tobi1*, Wan Hurani Osman ${ }^{2}$, Anna Lynn Abu Bakar ${ }^{3}$, Irma Wani Othman ${ }^{4}$
}

1 Pusat Penataran Ilmu dan Bahasa, Universiti Malaysia Sabah, Malaysia

Email: bernadette@ums.edu.my

2 Pusat Penataran Ilmu dan Bahasa, Universiti Malaysia Sabah, Malaysia

Email: wanosman@ums.edu.my

3 Pusat Penataran Ilmu dan Bahasa, Universiti Malaysia Sabah, Malaysia

Email: annalynn@ums.edu.my

$4 \quad$ Pusat Penataran Ilmu dan Bahasa, Universiti Malaysia Sabah, Malaysia

Email: irma@ums.edu.my

* Corresponding Author

\section{Article Info:}

\section{Article history:}

Received date: 15.05 .2021

Revised date: 24.06 .2021

Accepted date: 20.07 .2021

Published date: 31.07 .2021

To cite this document:

Tobi, B., Osman, W. H., Abu Bakar, A. L., \& Othman, I. W. (2021). A Case Study On Students' Reasons For Not Switching On Their Cameras During Online Class Sessions. International Journal of Education, Psychology and Counseling, 6 (41), 216-224.

DOI: $10.35631 /$ IJEPC.641016
Abstract:

The COVID-19 pandemic has brought academic face-to-face classes to a halt, globally. Schools, higher institutions, and all learning centres were forced into emergency mode searching for platforms to ensure the continuity of teaching and learning (UNESCO, 2020). Online classes were made mandatory, and instructors curated lessons to best deliver their lessons. However, frustrations emerged where teachers shared their experience of talking to the abyss of their computer screens as students did not switch on their cameras during online lessons. A link to a Google form questionnaire which is quantitative (questionnaire), qualitative (short answer questions) in nature was given to the author's communicative English class students. Fifty students in an English communicative course responded and the chairperson of the course was interviewed (qualitative) to find challenges teachers faced in their online classes. The author focused on one issue - students' refusal to turn on their cameras. The findings revealed the main reasons for not turning on the cameras during lessons as lack of internet data, poor internet connection, social norms, not being physically presentable, and not being comfortable to be looked at by peers. Instructions from teachers and class assessments affect students' choice 
Volume 6 Issue 41 (July 2021) PP. 216-224

DOI 10.35631/IJEPC.641016

Special Issue: Supporting the Continuation of Language Teaching and Learning at Malaysian Higher Education Institution

This work is licensed under $\underline{\mathrm{CC} B Y}$ 4.0

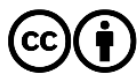

to turn on the camera, too. These findings serve as knowledge contributions for teachers to understand students and to do content curation.

\section{Keywords:}

Video Camera, Online Classes, Poor Internet Connection, Online Class Anxiety

\section{Introduction}

The Covid-19 pandemic has brought the academic face-to-face classes to a halt, globally. Schools, higher institutions, and all learning centres were forced into emergency mode searching for platforms to ensure the continuity of teaching and learning (UNESCO, 2020). Online classes, virtual classes, synchronous classes were nothing new however, to depend solely on these platforms had caused many educators to be forced into searching a plateau of IT literacy. Studies have shown that conducting synchronous classes promote learning, interaction, student-centred tasks and provide opportunities to provide constructive comments (Racheva, 2018). Many learning institutions offer crash courses and give talks on using the best perceived platforms to herald the changes in cascading knowledge to learners. Educators who are more IT literate than others offer assistance to those who used to flinch at any mention of teaching involving IT and electronic gadgets. In barely a year, Google Meet, Zoom, Microsoft Team, Voov, YouTube among many have now wagged the tongues of almost every educator.

Contented with the search for the best online sessions' platforms, educators were abruptly hit with the reality that they were destined to face students who were lost in the abyss of teachers' laptop screens. Students' refusal to switch the camera on had become a common teachers' grievance as reported by the course chairperson (N. Mahmood, personal communication, July $5,2021)$. Teachers' frustrations have led researchers to investigate the reasons for this problem. Studies have shown that online teaching and learning relied heavily on the availability of teaching and learning facilities, the availability of technology and of course, the readiness of both students and the instructors to be online (Mustofa et al., 2019; Firman \& Rahayu, 2020). However, not many studies have been conducted in this matter - students, unless forced, tend to switch off their devices' cameras during online classes. This qualitative and quantitative study aimed to uncover reasons why students in Malaysia prefer to turn off their video cameras during classes. The study attempts to assist institutions and teachers to overcome challenges and hurdles faced by both teachers and students.

\section{Literature Review}

Most educators are now familiar with online classes preparations and platforms. Some even go to the extent of creating 'mini studios' by investing in gadgets and devices to help them better deliver their lessons. They have geared up and curated lessons to achieve their courses objectives. Synchronous and asynchronous lessons are being curated to ensure students grasp the objectives. In fact, some educators are more excited than their students during class sessions as experienced by the author and the course chairperson. 


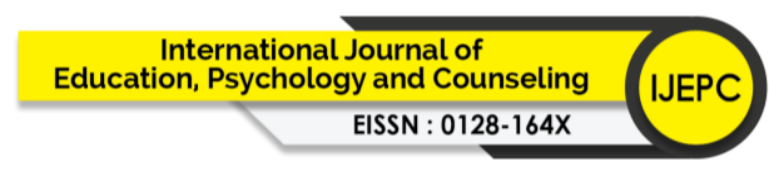

Volume 6 Issue 41 (July 2021) PP. 216-224

DOI 10.35631/IJEPC.641016

Special Issue: Supporting the Continuation of Language Teaching and Learning at Malaysian Higher Education Institution

Many students seemed to be more comfortable not turning on the cameras during synchronous class sessions. Some students would only turn their cameras on when requested by the instructors. It is every instructor's dream to be able to get students to turn on their cameras during lessons. However, Trust (2020) mentioned that in their excitement of using technology for teaching and learning, educators may unintentionally endangered students by violating their privacy rights and risk their safety.

Ever since online classes have been implemented, teachers grieved over teaching to empty spaces as students tend to switch off their devices' cameras. Educators in many institutions have required students to switch on their cameras to see if students are involved, participating, or confused (Will, 2020). A synchronous class session can be challenging for both teachers and students if it lacks non-verbal communication (Khalil, et. al., 2020); hence, the need for students to switch on their cameras. In Malaysia, students are advised to dress appropriately and if the internet coverage and data permit, to switch on their cameras so teachers can see students 'live' (Murniati, 2020). Unfortunately, uneven internet connection hinders online learning for students who have limited device availability (shared devices among siblings) and locations with unstable internet coverage (Yeoh, 2020; Lim, 2020; Teoh, 2020).

A study in Romania found that more than half of the 407 subjects disagreed to keep their cameras switched on during lessons because of security, nervousness, and privacy reasons (Gherhes, et. al., 2021). Castelli and Sarvary (2021) found that the most frequent reasons for switching off the camera was students' physical appearance followed by being concerned of people looking at their physical location in the background and poor internet connection. Nur Salina, et. al., (2020) reported that low internet bandwidth affects the implementation of remote learning in Malaysia which include camera usage during class sessions.

\section{Methodology}

\section{Study Design}

The study used a mixed method approach by utilizing Google form questionnaires to collect quantitative data from the students on reasons for turning off their cameras during classes. An interview with the course chairperson was also conducted to get the qualitative data from teachers' feedback on online teaching and learning.

\section{Course Description}

This communicative English course requires students to work in groups and to collaborate in performing mock interviews, meetings, and presentations via online platforms hence the need to switch on their cameras. All class sessions were held on Google Meet platform synchronously once a week. Videos were also provided asynchronously to enhance students' understanding of certain tasks and lessons. Links to the class sessions were posted in the class Telegram chat group about 30 minutes before class at 11AM on weekdays. Class duration was between 1 hour 30 minutes to 2 hours. Some students had other online sessions before and after their English class. Each class session had 30 enrolled students. 


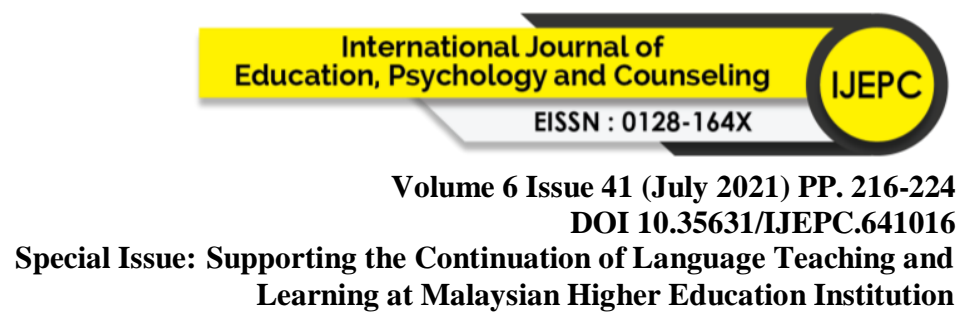

\section{Student Sample}

The researcher used her own classes as samples and fifty students responded. The samples were undergraduates in a public university, and they had experienced fully online classes the semester before. Geographically, students were scattered all over Malaysia. Students were assigned to the class Telegram group and the university learning management system (LMS), where the instructor disseminated class information, shared course notes and where students hand in their tasks. Students were encouraged to engage with each other and with the instructor through this chat group. The instructor also allowed students to private message her through Telegram if students needed further clarification and when discretion was required.

\section{Survey Question}

The Google form link was shared on Telegram with 60 students under one instructor and students were told to take the survey without obligation. The link to the survey was posted in the class Telegram group at the final week of the course. Fifty students responded to the survey.

The online survey was to gauge students' reasons for not switching on their cameras during online class sessions. The questionnaire was divided into demographic information - gender and location, availability of internet connection, reasons for switching off their cameras during online classes. The final part was a short answer segment on occasions where they are required to switch on their cameras.

\section{Findings}

Only a handful of students would turn on their cameras to greet the instructors when students joined Google Meet class. They would then turn off their cameras when class began as experienced and reported by both the chairperson and the author.

There were 48 females and 2 males who participated in the Google Form survey. The students were from all over Malaysia with 77.6\% from Sabah, 12.2\% from Sarawak and 10.2\% from West Malaysia.

The response on their internet connection included 5 students with excellent coverage except for bad weather, 25 students with minimal internal disturbance, 22 students with moderate internet disturbance, 7 students had difficulty to get internet connection and 1 student had to go to another location to get internet connection.

\section{Reasons for not Switching on the Camera during Online Classes}

On reasons for not switching on their cameras during online class sessions, each student could select more than one reason from the given list. There were 27 students who were concerned with their internet data if they switched on their cameras; 25 students had uneven internet connection; 23 students were worried about their background or the physical condition of their location (not nice background) and the same number of students were worried they did not look good online; 21 students felt uneasy being looked at; 16 students were concerned what their classmates would see behind them; 14 students were worried they would distract their instructor; 13 students did not want others to see that they were doing other work during class; 


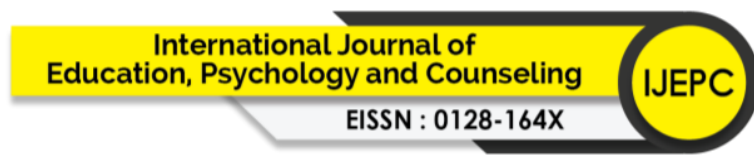

Volume 6 Issue 41 (July 2021) PP. 216-224

DOI 10.35631/IJEPC.641016

Special Issue: Supporting the Continuation of Language Teaching and Learning at Malaysian Higher Education Institution

9 students mentioned that they did not want others to see them not paying attention in class; 7 students had faulty cameras; and 1 student each was worried that switching on camera could lag the internet connection, not dressed appropriately for class, poor camera quality and no internet connection.

In general, the main reasons for not switching on their cameras are:

1. Students were afraid that they did not have enough internet data for other online sessions

2. Students had poor internet connection

3. Students were embarrassed of the physical condition of their location/ homes

4. Students were worried that they did not look good online

5. Students were uncomfortable being looked at the time

\begin{tabular}{|l|c|c|}
\hline Reasons & $\begin{array}{c}\text { Number of } \\
\text { Students } \\
(\mathrm{n}=50)\end{array}$ & Percentage \\
\hline 1. Fear of insufficient internet data & 27 & $54 \%$ \\
\hline 2. Poor internet connection & 25 & $50 \%$ \\
\hline 3. Physical condition of students' background/location & 23 & $46 \%$ \\
\hline 4. Physical appearance on camera (not looking good) & 23 & $46 \%$ \\
\hline 5. Uncomfortable to be looked at all the time & 21 & $42 \%$ \\
\hline
\end{tabular}

Table 1: Main Reasons for Not Switching on the Camera during Class

It can be inferred that students are concerned about not having enough internet data for their classes, worried about the uneven internet coverage, embarrassed of what others could see in their screens - either the location or their physical appearance - and are unnerved at stares from their peers.

\section{Response If Switching on Camera Is Compulsory}

This section allowed students to tick more than one statement. In response to the question of how students felt if an instructor insisted on switching on the camera during class sessions, 32 (64\%) students mentioned that they would willingly switch on their cameras; 23 (46\%) students would switched on their cameras but worried about not having enough data for their next class; $14(28 \%)$ mentioned that they would inform their lecturer that they could not switch on their cameras; $9(18 \%)$ mentioned that they would switch on the camera but worried about the expenses incurred in buying more internet data; another $9(18 \%)$ said they would unhappily turn on their cameras; 6 (12\%) students mentioned that they would just keep quiet and ignore the instruction to turn on the camera; $5(10 \%)$ students mentioned that they were worried about buying more data; $1(2 \%)$ student mentioned leaving the session if pressured to switch on the camera, $1(2 \%)$ student would switch on the camera if proper appearance permits and 1 (2\%) student would switch on only if all others students switched their cameras on, too. 


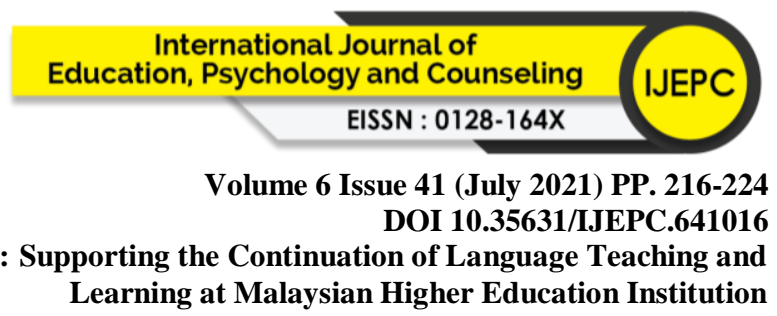

As revealed in the findings more than half of the students (64\%) are willing to switch on their cameras if they have internet coverage and internet data. Hence, it can be inferred that turning on their cameras is dictated by their geographical location and internet coverage. Another $46 \%$ are worried that turning on their cameras may use up their internet data and affect their attendance in other classes. The volition to switch on the cameras is there however, the fear of not being able to attend other classes deter them to do so. It also shows that some students $(28 \%)$ will inform their teachers of their predicaments, whilst $18 \%$ will just quietly and discontentedly switch on their cameras. The findings also revealed that $12 \%$ of students will just keep quiet and ignore the teacher's instruction. When forced to turn on the camera, one student (2\%) will just leave the class session. Another person (2\%) will only turn on the camera if other students do so. It can be inferred that most students are not inclined to switch on the camera because the majority do so. Internet connection and internet data availability seemed to be the predictor in determining students to switch on their cameras.

\begin{tabular}{|l|c|c|}
\hline Responses to Compulsory Camera Usage & $\begin{array}{c}\text { Number of } \\
\text { Students } \\
(\mathrm{n}=50)\end{array}$ & Percentage \\
\hline 1. Willingly switch the camera on & 32 & $64 \%$ \\
\hline 2. Switch on camera but worried if internet data is sufficient & 23 & $46 \%$ \\
\hline 3. Inform instructor of their refusal to switch on the camera & 14 & $28 \%$ \\
\hline 4. Switch on camera but worried of incurred expenses & 9 & $18 \%$ \\
\hline 5. Ignore instructions to switch on camera & 6 & $12 \%$ \\
\hline
\end{tabular}

\section{Table 2: Students' Response to Compulsory Camera Usage}

\section{Obligatory to Switch on Camera}

This part allowed students to express their opinions if switching on their cameras was made obligatory during class sessions.

In the final section of the survey, $9(18 \%)$ students mentioned that they would switch on their cameras for class if they need to do class presentations. Here are some comments students wrote:

- I have presentation and the lecturer is angry if I did not open the camera

- Class for a particular subject requires students to turn on the camera, or I have to turn on the camera while doing presentation

- If I had an assessment that required us to switch the camera on such as an interview assessment or oral exam.

- Lecturer insists told me to turn on camera

- If the lecture( $r$ ) is strict and cannot negotiation

- That's what my lecturer want

- It is presentation and the lecturer want to see the student face when talking

- However, some would only turn on the camera in these situations. 
Volume 6 Issue 41 (July 2021) PP. 216-224

DOI 10.35631/IJEPC.641016

Special Issue: Supporting the Continuation of Language Teaching and Learning at Malaysian Higher Education Institution

- My data connection is good and enough

- My internet connection is good and had a nice background with not crowded area.

- In the good connection and unlimited data internet

- My data connection is good and enough.

These findings indicate that more than half of the students were willing to switch on their cameras if there was a need to do so. Most students concurred that they would turn on their cameras for class presentations or assessments and if the teacher insisted their cameras be switched on. Nevertheless, switching on the cameras would depend on good internet connection and availability of internet data. Switching on the camera also depends on the rapport between students and teachers. Students also mentioned that teachers who are 'strict and cannot negotiate' and 'lecturer is angry' did make students switch on their cameras but at the same time could instill fear and could increase students' level of anxiety.

\section{Conclusion}

The findings are relatively congruent to the literature review - poor internet connection is the main reason for online class disruptions. Lagging or uneven connection forced students to not switch on their cameras during class sessions; financial constraint reduced the desire to use the camera. Social norms are also mentioned to affect camera usage. It is good to know that most students are willing to turn on their camera contingent on good internet connection and internet data availability.

Many students are now at the safety of their homes and the geographical landform does affect internet connections as numerously mentioned in the local newspapers (Lim, 2020; Teoh, 2020; Yeoh, 2020). Financial constraint is also another reason that should not be ignored. During this pandemic, many households are financially affected (Rohiman, 2021). Buying internet data may mean missed meals in some families. Instructors need to be more sensitive to the predicaments students are experiencing. Students are also concerned with the physical appearance of their home. Switching on the camera means the embarrassment of letting others see their humble homes. A study by Reich et al., 2020 found that students who are less fortunate do not want their more prosperous peers to see their homes and some students go to the extent of going online inside a closet for privacy. Students may also feel that to show their faces means they have to look good and when they feel that they do not look their best, they refuse to turn on the camera. This pandemic has increased students' anxiety and depression level (Huckins et al., 2020) and to make students switch on their cameras may add to their already depressing and traumatic online learning problems (Costa, 2020). As revealed by the findings, "angry" teachers who insisted that students need to turn on their cameras may further distress students.

The number of samples in this case study is small and more studies are needed to investigate the veracity of these claims, nonetheless, educators can at least now know the reasons why students are unable to switch on their cameras in the Malaysian setting. This challenging period and online classes are likely to persist; thus, hopefully, this paper will serve as a review for instructors to know their students' predicaments and plan their lessons either synchronously or 


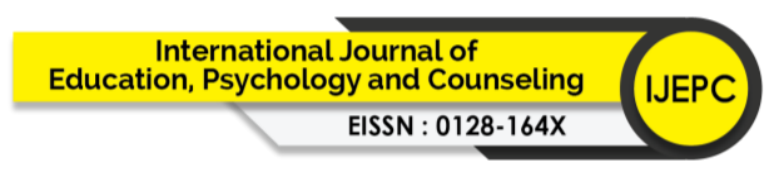

Volume 6 Issue 41 (July 2021) PP. 216-224

DOI 10.35631/IJEPC.641016

Special Issue: Supporting the Continuation of Language Teaching and

Learning at Malaysian Higher Education Institution

asynchronously, accordingly. These findings serve as knowledge contributions for teachers to anticipate online learning problems, and to curate lessons best suited to their students. With the information gained, it is hoped that instructors can plan lessons, manage their online classes better, enhance teaching practice and professionalism, and reforge teaching and learning norms.

\section{References}

Castelli, F., \& Sarvary, M. (2021). Why students do not turn on their video cameras during online classes and an equitable and inclusive plan to encourage them to do so. Ecology and Evolution. 10.1002/ece3.7123.

Costa, K. (2020). Cameras be damned. LinkedIn. Retrieved from https://www.linke din.com/pulse/ camer as-damne d-karen -costa/. Accessed July 30, 2021.

Davis, F. (1989). Perceived Usefulness, Perceived Ease of Use, and User Acceptance of Information Technology. MIS Quarterly, 13(3), 319-340. doi:10.2307/249008

Firman, F., \& Rahayu, S. (2020). Pembelajaran Online di Tengah Pandemi Covid-19. Indonesian Journal of Educational Science (IJES), 2(2), 81-89. https://doi.org/10.31605/ijes.v2i2.659

Gherheș, V., Șimon, S., \& Para, I. (2021). Analysing Students' Reasons for Keeping Their Webcams on or off during Online Classes. Sustainability, 13(6), 3203. doi:10.3390/su13063203

Huckins J., daSilva A., Wang W., Hedlund E., Rogers C., Nepal S., Wu J., Obuchi M., Murphy E., Meyer M., Wagner D, Holtzheimer P, Campbell A. (2020). Mental Health and Behavior of College Students During the Early Phases of the COVID-19 Pandemic: Longitudinal Smartphone and Ecological Momentary Assessment Study J Med Internet Res 2020;22(6):e20185 URL: https://www.jmir.org/2020/6/e20185 DOI: $10.2196 / 20185$

Khalil, R., Mansour, A.E., Fadda, W.A. et al. The sudden transition to synchronized online learning during the COVID-19 pandemic in Saudi Arabia: a qualitative study exploring medical students' perspectives. BMC Med Educ 20, 285 (2020). https://doi.org/10.1186/s12909-020-02208-z

Lim, I. (2020, May 30). Reality for Malaysia's University students: Online learning challenges, stress, workload; possible solutions for fully digital future until Dec. Malay Mail. Retrieved from https://www.malaymail.com/news/malaysia/2020/05/30/realityfor-malaysias-university-students-online-learning-challenges-stress/1870717

Murniati, A. K. (2020, July 1). Making the best of online lessons. The New Straits Times. Retrieved from https://www.nst.com.my/education/2020/07/605108/making-bestonline-lessons

Mustofa, M., Chodzirin, M., Sayekti, L., \& Fauzan, R. (2019). Formulasi Model Perkuliahan Daring Sebagai Upaya Menekan Disparitas Kualitas Perguruan Tinggi. Walisongo Journal of Information Technology, 1(2), 151-160. https://doi.org/10.21580/wjit.2019.1.2.4067.

Nur Salina I., Nor Mazlina A. B., Sharifah Wajihah Wafa S. S. T. W. (2020). Online Learning Challenges during Pandemic COVID-19 in Malaysian Higher Learning Institution. Universal Journal of Educational Research, 8(12), 7151 - 7159. DOI: 10.13189/ujer.2020.081282 


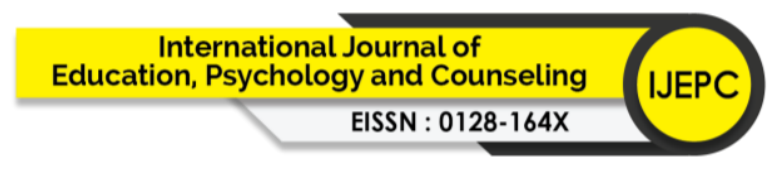

Volume 6 Issue 41 (July 2021) PP. 216-224

DOI 10.35631/IJEPC.641016

Special Issue: Supporting the Continuation of Language Teaching and Learning at Malaysian Higher Education Institution

Racheva, V. (2018). Social aspects of synchronous virtual learning en-vironments. AIP Conference Proceedings, 2048, 020032. https://doi.org/10.1063/1.5082050

Reich, J., Buttimer, C. J., Coleman, D., Colwell, R. D., Faruqi, F., \& Larke, L. R. (2020, July 22). What's Lost, What's Left, What's Next: Lessons Learned from the Lived Experiences of Teachers during the 2020 Novel Coronavirus Pandemic. https://doi.org/10.35542/osf.io/8exp9

Rohiman, H. (2021, July 4). White flag movement an initiative by the people, for the people. New Strait Times Retrieved from https://www.nst.com.my/opinion/columnists/2021/07/704879/white-flag-movementinitiative-people-people

Teoh, M. (2020, November 20) Barriers to online learning. The Star. Retrieved from https://www.thestar.com.my/lifestyle/family/2020/11/20/barriers-to-online-learning

Trust, T. (2020) The 3 Biggest Remote Teaching Concerns We Need to Solve Now. https://www.edsurge.com/news/2020-04-02-the-3-biggest-remote-teachingconcerns-we-need-to-solve-nowences

UNESCO. (2020, May 25). COVID-19 educational disruption and response. Retrieved from https://en.unesco.org/themes/education-emergencies/coronavirus-school-closures

Will, M. (2020, October 20). Most Educators Require Kids to Turn Cameras On in Virtual Class, Despite Equity Concerns. Education Week https://www.edweek.org/teachinglearning/most-educators-require-kids-to-turn-cameras-on-in-virtual-class-despiteequity-concerns/2020/10

Yeoh, A. (2020, April 27) MCO: As lessons move online, local teachers and students struggle with uneven Internet access. The Star. Retrieved from https://www.thestar.com.my/tech/tech-news/2020/04/27/mco-as-lessons-moveonline-local-teachers-and-students-struggle-with-uneven-internet-access 